\title{
GENDERED CAREER PRODUCTIVITY AND SUCCESS IN ACADEMIA IN INDONESIA'S ISLAMIC HIGHER EDUCATION INSTITUTIONS'
}

\author{
Nur Kholis \\ IAIN Sunan Ampel, Surabaya - Indonesia
}

\begin{abstract}
Career advancement in Indonesian academia is nationally regulated. It, theoretically, provides equal opportunities for men and women to be productive and successful. The purpose of this study is to analyze gender effects on academic career productivity and success. Sevenhundred and fifty questionnaires were distributed randomly to eight Islamic Higher Education Institutions in seven provinces, from which 220 (Men $=57.7 \%$, and Women $=$ $42.3 \%$ ) respondents returned the questionnaires with an analyzable quality. Descriptive and multivariate analyses are employed for analyzing and presenting the results. The paper argues that women in Islamic Higher Education Institutions are less productive in terms of publications, hold lower academic rank and leadership positions, and earn significantly less than men. It further argues that Islamic Higher Education Institutions should provide specific empowerment for women by, for example, providing support for their continuing education, professional development, and career opportunities.
\end{abstract}

Keywords: Gender, Academia, Career Productivity, Career Success.

\section{Introduction}

Within the global competition era, fueled with the advances in technology, universities face new challenges never encountered before.

\footnotetext{
1 The earlier version of this paper was presented at The $12^{\text {th }}$ Annual International Conference on Islamic Studies (AICIS), held by the Ministry of Religious Affairs and the State Institute of Islamic Studies (IAIN) Sunan Ampel, Surabaya, 5-8 November 2012.
} 
Members' expertise emerges as one of the crucial human assets to raise the bargaining positions and competitive advantages of the university. Career management is, and should be, a significant component in the policy development of the university. The reason is that the value and the quality of the university are often evaluated on whether their staff members are productive, and whether their products are accepted and contribute the best in the labor market. A full development of staff potentials is crucial in the efforts to produce the best labor market. Failure to fulfill this endeavor would mean not only wasting important talents the staff would offer to the organization but also opening the path to a lower performance of staff and the organization alike.

Career advancement in Indonesian academia is nationally regulated, and all regulations should be adopted into practices. This, in theory, provides equal opportunities for women and men to have academic products equally and, then, to achieve an equitable success. It is argued here, however, that instigating formal human resource policies alone may not ensure the associated processes and practices are equal, ${ }^{2}$ thereby resulting in equal productivity and success among staff members. In addition, informal structure and organizational culture may override the formal policy. ${ }^{3}$ For example, the equally perceived distribution of resources may end up in favoring a certain group of staff members.

The question remains whether the implemented policy and practices affect the university staff similarly or differently, especially when gender is taken into account. This study aims at analyzing gender effects on career productivity and career success among men and women academics in Indonesian academia. Two important questions deserve a thorough analysis; first, are women less productive than men? Second, are women less successful than men?

\section{Reviewing Career Productivity and Success in Academia}

Generally, career productivity in academia is measured through three pillars of academic activities: teaching, research, and community

\footnotetext{
2 S. Loughlin, "Barriers To Women's Career Progression: A Review of The Literature," http://www.ssc.govt.nz. Working Paper No. 6. The State Services Commission New Zealand. Crown, NZ, 2000.

3 M. Ismail, "Barriers to Career Progression Faced By Women: Evidence From A Malaysian Multinational Oil Company," Gender in Management: An International Journal, 23, 1 (2008): pp. 51-66.
} 
service. The evaluation results of these activities are often used as a basis for promotion. However, the weighing approach applied to the three activities depends on the university system. Similarly, in Indonesian academia staff members are evaluated against the basic purpose of university management and operation, called Tri Dharma Perguruan Tinggi (Three Main Duties of Higher Education). ${ }^{4}$ The activities should be performed by all academic staff members, from education, teaching, research, publications, to community service and supporting activities. ${ }^{5}$ Thus, all academic staff members are expected to meet these standards during their career. Academic staff failing to meet these criteria may be subjected to being unproductive.

Academic career literature indicates that women are less productive than men. In publication, for example, several studies revealed consistent results; men publish more than women in most of the scientific fields. ${ }^{6} \mathrm{D}^{\prime}$ Amico and $\mathrm{Canetto}^{7}$ find that men have a higher publication rate and impact than women, as well as have more publications. In the field of ecology and evolutionary biology men published almost $40 \%$ more papers than women on average. ${ }^{8}$ Another study suggests that women have up to $35 \%$ fewer publications than men. ${ }^{9}$ In addition, Hancock and Baum ${ }^{10}$ maintain that men scored

\footnotetext{
${ }^{4}$ Indonesian Govt, Peraturan Pemerintah Republik. Indonesia Nomor 60 Tabun 1999 tentang Perguruan Tinggi (Government Regulation on Higher Education).

${ }^{5}$ Coordinating Minister, Keputusan Menteri Koordinator Bidang Pengawasan Pembangunan dan Pendayagunaan Aparatur Negara No. 38/KEP/MK. WASPAN/8/1999 Tentang Jabatan Fungsional Dosen dan Angka Kreditnya (The Minister Decree on the Functional Positions of Lecturers and their Credit Numbers).

6 B. Hemmings, P. Rushbrook and E. Smith, "Academics' Views on Publishing Refereed Works: A Content Analysis," Higher Education, 54, 2 (2007): pp. 307-32.
}

${ }^{7}$ R. D'Amico and S. S. Canetto, "Similarities and Differences in Women's and Men's Publication and Citation Record Among Academic Psychologists," Journal of Women and Minorities in Science and Engineering, 16, 4 (2010): pp. 343-61.

${ }^{8}$ M. R. E. Symonds, N. J. Gemmell, T. L. Braisher, K.L. Gorringe and M.A. Elgar, "Gender Differences in Publication Output: Towards An Unbiased Metric of Research Performance," PLoS ONE, 1, 1 (2006): p. e127.

9 C. Kirchmeyer, "The Different Effects of Family on Objective Career Success Across Gender: A Test of Alternative Explanations," Journal of Vocational Behavior, 68, 2 (2006): pp. 323-46.

10 K. J. Hancock, and M. Baum, "Women and Academic Publishing: Preliminary Results From A Survey of The ISA Membership" (Paper presented at the The International Studies Association Annual Convention, New Orleans, LA, 2010). 
modestly higher than women in the publication of articles and book chapters, but not books. The most recent research also discovers that women published fewer articles throughout their careers than men. ${ }^{11}$

Previous research also indicates that compared to men women faculty members prefer to spend a greater percentage of their time on teaching, while men prefer to spend more time on research. Women also tend to spend a greater percentage of their workweek on teaching and a smaller percentage on research than men. ${ }^{12}$ There is also a tendency that women face a difficulty in attending academic conferences due to domestic arrangements, especially when the conference takes few days. ${ }^{13}$ What these literatures suggest is that women are less likely able to meet the academic work compared to their male counterparts.

Apart from that, career success has been defined as the positive psychological or work-related outcomes or achievements individuals have accumulated as a result of their work experiences. ${ }^{14}$ Career success is typically conceptualized along two dimensions: objective (extrinsic) and subjective (intrinsic)..$^{15}$

Objective career success is the structural and public aspect of a person's career, as measured against objective, verifiable and measurable (in an interpersonal way) criteria such as span of control, income or salary level, advancement or promotion rank, and occupational status. ${ }^{16}$ Subjective career success, on the other hand, is

${ }^{11}$ D. Reed, F. Enders, R. Lindor, M. McClees and K. Lindor, "Gender Differences in Academic Productivity and Leadership Appointments of Physicians Throughout Academic Careers," Acad Med, 86, 1 (2011): pp. 43-7.

12 S. Winslow, "Gender Inequality and Time Allocations Among Academic Faculty," Gender \& Society, 24, 6 (2010): pp. 769-93.

13 Berges, S., "Women And Academic Conferences," from http://www.vitae.ac.uk/researchers/502241-352611/Women-and-academic-conferences.html (2011)

14 T. W. H. Ng, L. T. Eby, K. L. Sorensen, and D. C. Feldman, "Predictors of Objective and Subjective Career Success: A Meta-Analysis," Personnel Psychology, 58 (2005): pp. 367-408.

${ }^{15}$ I. E. De Pater, "Doing Things Right Or Doing The Right Thing: A New Perspective on The Gender Gap in Career Success" (Unpublished Ph.D Dissertation, Universitiet van Amsterdam, 2005).

16 M. L. Kern, H. S. Friedman, L. R. Martin, C. A. Reynolds, and G. Luong, "Conscientiousness, Career Success, And Longevity: A Lifespan Analysis," Annals of Behavioral Medicine, 37 (2009): pp. 154-63. 
the individual's assessment of both objective and subjective rewards in his or her career, including the meaning that individuals attribute to their career and its evaluation according to personal criteria such as satisfaction. The subjective judgment is influenced by both objective criteria and individual aspiration levels, social comparisons to relevant others, and situational constraints such as opportunities for advancement in a profession. ${ }^{17}$

In academia, objective measures include academic rank, tenure, promotion, salary, reputation, and honorific awards; ${ }^{18}$ speed of tenure, resignation, and speed of promotion, ${ }^{19}$ earnings ${ }^{20}$, and leadership. ${ }^{21}$ Among indicators to measure subjective career success are career engagement ${ }^{22}$ and career satisfaction. ${ }^{23}$ The measurement of subjective career success has been carried out extensively in professional (such as accountants, engineers, insurance agents, research scientists) and nonprofessional groups (including assembly workers and nurses). In

${ }^{17}$ S. E. Seibert, M. L. Kraimer, and R. C. Liden, "A Social Capital Theory of Career Success," The Academy of Management Journal, 44, 2 (2001): pp. 219-37.

18 A. E. Bayer, and H. S. Astin, "Sex Differentials in The Academic Reward System," Science, 188, 4190 (1975): pp. 796-802.

19 M. J. Dunkin, "Determinants of Academic Career Advancement at An Australian University," Higher Education Research \& Development, 10, 2 (1991): pp. 115-31.

${ }^{20}$ M. L. v. Engen, I. L. Bleijenbergh, and Vinkenburg, Structural and Cultural Barriers For The Advancement of Women at Delft University of Technology (Delft, NL.: Delft University of Technology, 2010).

${ }^{21}$ N. C. Tiao, "Senior Women Leaders in Higher Education: Overcoming Barriers to Success" (Unpublished Ph.D Dissertation, Eastern Michigan University, Ypsilanti, Michigan, 2006).

22 W. B. Schaufeli, A. B. Bakker, and M. Salanova, "The Measurement of Work Engagement With A Short Questionnaire," Educational and Psychological Measurement, 66, 4 (2006): pp. 701-16.

23 J. H. Greenhaus, S. Parasuraman, and W. M. Wormley, "Effects of Race on Organizational Experiences, Job Performance Evaluations, and Career Outcomes," Academy of Management Journal, 33 (1990): pp. 64-86; C. Kirchmeyer, "Determinants of Managerial Career Success: Evidence and Explanation of Male/Female Differences," Journal of Management, 24, 6 (1998): pp. 673-92; Ng, et.al., Personnel Psychology, pp. 367408. 
contrast, the application of subjective career success in academia has literally been ignored by researchers. ${ }^{24}$

Literature of academic career indicates that there are universal gender differences in academic rank and leadership position, ${ }^{25}$ with women being under-represented at senior levels in academia ${ }^{26}$ and at leadership positions in university. ${ }^{27}$ Similarly, women generally earn less income than men. For example, average salary for female faculty is roughly 80 percent of their male counterparts especially at higher ranks. ${ }^{28}$ In Japanese academia a 7.3\% gender salary gap was found, ${ }^{29}$ and in 2009 and 2010 male professors in the US tertiary institutions earned about 14 to $15 \%$ more than female professors. ${ }^{30}$

${ }_{24}$ T. Baş, and K. Ardıç, "A Comparison of Job Satisfaction Between Public and Private University Academicians in Turkey," METU Studies in Development, 29, 1-2 (2002): pp. 27-46.

25 A. E. Bayer, and H. S. Astin, "Sex Differentials in The Academic Reward System," Science, 188, 4190 (1975): pp. 796-802.

${ }^{26}$ M. Sabatier, M. Carrere, and V. Mangematin, "Profiles of Academic Activities and Careers: Does Gender Matter? An Analysis Based on French Life Scientist CVs," Journal of Technology Transfer, 31 (2006): pp. 311-24; K. Sanders, T. M. Willemsen, and C. C. J. M. Millar, "Views From Above The Glass Ceiling: Does The Academic Environment Influence Women Professors' Careers And Experiences?,” Sex Roles, 60, 5-6 (2009): pp. 301-12; F. Wright, and J. Guth, "Women in The Higher Education Sector," The Industrial Law Journal, 38, 1 (2009): pp. 139-42.

27 AVCC, "Vice-Chancellors," Retrieved November 11, 2008, from http://www.universitiesaustralia.edu.au/content.asp?page=/about/current office hol ders/VCs.htm; H. Eggins, "Women in Higher Education, Research and Innovation: Gains and Further Challenges" (Paper presented at the 2009 World Conference on Higher Education, Paris, 5-8 July 2009, Unesco Paris).

${ }^{28}$ K. Monroe, S. Ozyurt, T. Wrigley, and A. Alexander, "Gender Equality in Academia: Bad News From The Trenches, and Some Possible Solutions," Perspectives on Politics, 6, 2 (2008): pp. 215-33.

29 A. M. Takahashi, and S. Takahashi, "Gender Salary Differences in Economics Departments in Japan" (Paper presented at the Kansai Labour Seminar, Osaka University, 2009).

${ }^{30}$ L. G. Knapp, J. E. Kelly-Reid, and S. A. Ginder, "Employees in Postsecondary Institutions, Fall 2009, and Salaries of Full-time Instructional Staff, 2009-10 (NCES 2011-150). U.S. Department of Education," (Washington, DC: National Center for Education Statistics. Retrieved August 17, 2011, from http://nces.ed.gov/pubsearch) 
Research has found correlation between gender and work engagement. ${ }^{31}$ An online survey also reports that in India men reported a higher engagement in work count than women did by eight percent on "fully engaged" score. ${ }^{22}$ Gender differences in the dimensions of work engagement are also found: men reported higher levels of vigor and dedication than women ${ }^{33}$ and women who have part-time work experiences indicated lower levels of both vigor and dedication. ${ }^{34}$ Another study suggests that male employees scored higher on the dimension of vigor and absorption while female employees gained more scores on the dimension of dedication. ${ }^{35}$

In academe, men are usually happier with working conditions; the satisfaction gap, however, varies by discipline. ${ }^{36} \mathrm{~A}$ study on practicing psychiatry maintains that women reported more satisfaction with their careers than men. ${ }^{37}$ Nonetheless, in the engineering and social science fields, there was no significant difference in satisfaction levels for men and women. ${ }^{38}$ Yet, female academic gastroenterologists reported less overall career satisfaction and promotion than male academic

${ }^{31}$ D. A. Otwori, and L. Xiangping, "Empirical Study on Occupational Engagement of Kenyan Cultural Officers," Far East Journal of Psychology and Business, 1, 1 (2010): pp. 314.

32 BlessingWhite, "The Employee Engagement Equation in India," BlessingWhite. Retrieved August 21, 2011, from www.blessingwhite.com/content/reports/blessingwhite 2011 ee report.pdf

${ }^{33}$ R. J. Burke, and G. El-Kot, "Work Engagement Among Managers and Professionals in Egypt: Potential Antecedents and Consequences," African Journal of Economic and Management Studies, 1, 1 (2010): pp. 42-60.

${ }^{34}$ R. J. Burke, and L. Fiksenbaum, "Work Engagement Among Women Managers and Professionals in A Turkish Bank," Equal Opportunities International, 25, 4 (2006): pp. 299-310.

35 Y. Kong, "A Study on The Job Engagement of Company Employees," International Journal of Psychological Studies, 1, 2 (2009): pp. 65-8.

${ }^{36}$ COACHE, The Experience of Tenure-Track Faculty at Research Universities: Analysis of COACHE Survey Results By Academic Area and Gender (Cambridge, MA: Harvard Graduate School of Education, 2010).

${ }^{37}$ P. E. Garfinkel, R. M. Bagby, D. R. Schuller, S. E. Dickens, F. S. Schulte, and L. Fitzgerald, "Gender Differences in The Practice Characteristics and Career Satisfaction of Psychiatrists in Ontario," Acad Psycbiatry, 28, 4 (2004): pp. 310-20.

38 M. Sabharwal and E. A. Corley, "Faculty Job Satisfaction Across Gender and Discipline," The Social Science Journal, 46 (2009): pp. 539-56. 
gastroenterologists. ${ }^{39}$ Oshagbemi ${ }^{40}$ argues that female academics at higher ranks are more satisfied with their jobs than male academics of comparable ranks. Variations in satisfaction occur, with female faculty being more satisfied with their work and co-workers, whereas their male colleagues are more satisfied with their pay, promotions, supervision and overall job satisfaction. ${ }^{41}$

\section{Notes on Methodological Framework}

The population of the study is all Public Civil Servants (PCS) lecturers employed in the Islamic State Higher Education Institutions (ISHIEs) in Indonesia. Recent data show that the number of PCS lecturers working ISHEIs was 11,966 (men 7,862 or $65.7 \%$ and women 4,104 or $34.3 \%$ ). ${ }^{42}$ According to Cohen's table of sample sizes for a probability sample, ${ }^{43}$ the sample taken from a population of more than 10,000 and fewer than 20,000 is 370 , with a confidence level $95 \%$ and a confidence interval of 5 . Because this study involves the gender subpopulation, the sample taken is divided half according to gender; thus, the ideal sample taken from the male subgroup is 185 and the female subgroup is 185. However, in this study the number of responses to the survey determines the final sample.

Questionnaires were randomly distributed to eight Islamic State Higher Education Institutions (ISHEIs) in seven provinces. Two hundreds and twenty-one (221) respondents returned questionnaires with analyzable quality $(\mathrm{Men}=57.7 \%$, and Women $=42.3 \%$ ). These came from South Kalimantan, West Nusa Tenggara, East Java, Central Java, West Java, Yogyakarta, Riau, and Aceh.

${ }^{39}$ L. Gerson, K. Twomey, G. Hecht, G., L. Lee, K. McQuaid, T. Pizarro, D. Early, "Does Gender Affect Career Satisfaction and Advancement in Gastroenterology? Results of An AGA Institute-Sponsored Survey," Gastroenterology, 132, 4 (2007): pp. 1598-606.

40 T. Oshagbemi, "Is Length of Service Related to The Level of Job Satisfaction?," International Journal of Social Economics, 27, 3 (2000): pp. 213-26.

${ }^{41}$ J. O. Okpara, M. Squillace, and E. A. Erondu, E. A. "Gender Differences and Job Satisfaction: A Study of University Teachers in The United States," Women In Management Review, 20, 2 (2005): pp. 177-90.

42 MoRA, Education Statistic 2007/2008 (Jakarta: Directorate of Islamic Higher Education, 2008).

43 L. Cohen, L. Manion, and K. Morrison, Research Methods in Education (6 ${ }^{\text {th }}$ ed.) (Abingdon, Oxon: Routledge, 2007), p. 104. 
Survey questionnaires are used containing demographic information, productivity indicators, and success indicators. Some items are open-ended questions and some are Likert 5 scale type; $1=$ Strongly disagree, and $5=$ Strongly agree. The questionnaires were distributed to the targeted ISHEIs selected on the basis of the data distributor availability. The questionnaire is a paper-based survey, and the strategy was so chosen because many of the respondents did not have a reliable internet connection. It was also assumed that paperbased survey would provide the respondents with ease in answering the questionnaires, so that a maximum return could be expected.

Exploratory analyses are used in this study. To examine possible gender differences in the demographic data, several $t$-tests and chisquare are applied. The multivariate analysis of variance (MANOVA) is used to measure effects of gender on selected dependent variables. The MANOVA tests were full factorial models with gender (men versus women) as factor and with age as control variable. In the analysis process, the selected variables for career productivity and success are entered as lists of dependents. All data analyses are performed with PASW Statistics 18 (SPSS) for Windows. ${ }^{44}$

Variables included in this study cover demographic information (gender, age, education level, marital status, parental status, spouse's education and occupation), productivity indicators (teaching credits, thesis supervision, research, scholarly presentation, publication, and committee appointment), and career outcomes (academic rank, leadership position, income, career satisfaction, and work engagement). Respondents were asked to give their actual age (in years) and to indicate their gender $(1=$ Male, $2=$ Female $)$; their highest educational level $(1=$ undergraduate, $2=$ Graduate diploma, $3=$ Master, and $4=$ $\mathrm{PhD})$; marital status $(1=$ Single $2=$ Married,); parental status $(1=\mathrm{Do}$ not have child(ren), 2 = Have child(ren)). They were also asked to select their spouse's education $(1=$ Until high school, 2 = Diploma, 3 $=$ Undergraduate, $4=$ Postgraduate, and $5=$ Doctorate), and their spouse's occupation $(1=$ Lecturer/Teacher, $2=$ PNS/Company staff, 3 = Entrepreneur, $4=$ Others, and $5=$ Does not work).

Respondents were asked to give the number of teaching credits in the previous year. Thesis supervision was gathered using a form requesting the respondents to put the number of theses they supervised based on

${ }^{44}$ SPSS, PASW® Statistics 18 Core System User's Guide (Chicago, IL.: SPSS Inc., 2009). 
the thesis category: $1=$ None, $2=$ Bachelor, $3=$ Master, $4=$ Doctorate. To measure research productivity respondents were asked to indicate the number of research projects completed within the last two years ranging from $1=$ None to $5=$ more than 3 , with a higher number indicating highly productive in research activity. Respondents were asked to give the number of scholarly presentation in the last year based on the presentation category: $0=$ None, $1=$ local, $2=$ national, and $3=$ international. Publications are comprised of two variables: book and journal publications. For book publications, respondents were asked to give the number of books they have published during their academic career. For journals, they were asked to indicate the types of journal and the number of articles they published over the last five years. The coded items were $1=$ No publication; $2=$ Popular magazine or newspapers; $3=$ Indonesian non-accredited journal; $4=$ Indonesian accredited journal; and $5=$ International journal. Finally, respondents were asked to provide the number of committee appointment based on the positions in the committee in the last year: $0=$ None, $1=$ Member, 2 = Coordinator, $3=$ Treasurer, $4=$ Secretary, $5=$ Head, and $6=$ Supervisor.

For academic rank, respondents were asked to give their current academic ranks. Their answers were then coded hierarchically according to the rank orders of PCS lecturers set out by the Indonesian government, ${ }^{45}$ being 1 = Expert Assistant; 2 = Lecturer; 3 $=$ Head Lecturer; 4 = Professor. For leadership position respondents were asked to give the name of position they currently have. Their answers were grouped into three leadership levels, and coded $1=$ Low position (department and unit levels); $2=$ Middle position (postgraduate and faculty levels); and $3=$ High position (university level). For monthly income respondents were asked to choose one of the eight salary categories, ranging from $1=\operatorname{IDR} 1-3$ million to $8=$ More than IDR 21 million.

Work engagement was measured with nine items developed by Utrecht Work Engagement Scale (UWES-9), on a 7-point response

45 Coordinating Minister, Keputusan Menteri Koordinator Bidang Pengawasan Pembangunan dan Pendayagunaan Aparatur Negara No. 38/KEP/MK. WASPAN/8/1999 Tentang Jabatan Fungsional Dosen dan Angka Kreditnya (The Minister Decree on the Functional Positions of Lecturers and their Credit Numbers). 
from $0=$ Never; $6=$ Always. $^{46}$ This scale originally contained three dimensions: vigor (3 items, e.g., At my work, I feel bursting with energy), dedication (3 items, e.g., I am enthusiastic about my job), and absorption (3 items, e.g., I feel happy when I am working intensely). We followed Sonnentag's ${ }^{47}$ and Christian ${ }^{48}$ et al.'s in using work engagement as a single construct in which higher score signifies higher engagement in work. In the present study, the combined Cronbach's alpha for the total nine-item scale was 0.90. Career satisfaction was measured with five items developed by Greenhaus, Parasuraman, and Wormley ${ }^{49}$ on a 5 -point scale ranging from $1=$ Strongly disagree to 5 $=$ Strongly agree, with a high score indicating high satisfaction with one's career. Two examples of items are "I am satisfied with the success I have achieved in my career" and "I am satisfied with the progress I have made toward meeting my goals for advancement." Cronbach's alpha in the present study was $\alpha=0.90$.

\section{Does Gender Affect the Productivity and Career Success of Academic Staff?}

Table 1, as can be seen below, shows relevant demographic information about the respondents in percentages by gender. The number of male respondents of this study is $n=127$ and that of women is $\mathrm{n}=94$. The majority of respondents have a Master's degree (74.1\%), and the second largest group has a Doctoral degree $(17.5 \%)$. While more men have a Master's degree, more women had a $\mathrm{PhD}$ degree. A few respondents held undergraduate degrees (7.5\%). The majority of those having undergraduate education are in the age of 45 to 64. On average male respondents are older $(M=43.6, S D=8.97)$ than female respondents $(M=40.5, S D=9.02), t(218)=2.58, p<$

46 W. B. Schaufeli, A. B. Bakker, and M. Salanova, "The Measurement of Work Engagement With A Short Questionnaire," Educational and Psychological Measurement, 66, 4 (2006): pp. 701-16.

${ }^{47}$ S. Sonnentag, "Recovery, Work Engagement, and Proactive Behavior: A New Look at The Interface Between Nonwork and Work," Journal of Applied Psychology, 88, 3 (2003): pp. 518-28.

48 M. S. Christian, A. S. Garza, and J. E. Slaughter, "Work Engagement: A Quantitative Review and Test of Its Relations With Task and Contextual Performance," Personnel Psychology, 64 (2011): pp. 89-136.

49 J. H. Greenhaus, S. Parasuraman, and W. M. Wormley, "Effects of Race on Organizational Experiences, Job Performance Evaluations, and Career Outcomes," Academy of Management Journal, 33 (1990): pp. 64-86. 
0.01, up to two years. Furthermore, most of the respondents are married (90.5\%); however, more male respondents are married $(M=$ $1.94, S D=0.24)$ than female respondents $(M=1.84, S D=0.35), \chi^{2}$ $(1, N=220)=3.49, \mathrm{p}<0.10$. In addition, the majority of respondents is parents/had children $(81.9 \%)$.

Table 1: Characteristic of Respondents

\begin{tabular}{|c|c|c|c|c|c|}
\hline \multicolumn{2}{|c|}{ Characteristics } & \multirow[t]{2}{*}{ Men } & \multirow[t]{2}{*}{ Women } & \multicolumn{2}{|c|}{ Statistics } \\
\hline & & & & $X^{2} / t$ & $P$ \\
\hline Gender & & $56.1 \%$ & $43.9 \%$ & $x^{2}=221.0$ & Ns \\
\hline \multirow[t]{4}{*}{ Highest education } & Undergraduate & $5.9 \%$ & $9.7 \%$ & $x^{2}=1.76$ & Ns \\
\hline & Postgraduate Diploma & $0.8 \%$ & $1.1 \%$ & & \\
\hline & Masters & $77.3 \%$ & $69.9 \%$ & & \\
\hline & Doctorate & $16.0 \%$ & $19.4 \%$ & & \\
\hline \multirow[t]{2}{*}{ Age } & & $M=43.6$ & $M=40.5$ & $t=2.58$ & ** \\
\hline & & $S D=8.97$ & $S D=9.02$ & & \\
\hline \multirow[t]{2}{*}{ Marital status } & Married & $93.7 \%$ & $86.2 \%$ & $x^{2}=3.49$ & \# \\
\hline & Single & $6.3 \%$ & $13.8 \%$ & & \\
\hline \multirow[t]{2}{*}{ Parental status } & Children & $85.0 \%$ & $77.7 \%$ & $\chi^{2}=1.99$ & Ns \\
\hline & No children & $15.0 \%$ & $22.3 \%$ & & \\
\hline \multirow[t]{3}{*}{ Spouse's education } & School level & $16.7 \%$ & $6.5 \%$ & $x^{2}=9.58$ & ** \\
\hline & Undergraduate level & $61.4 \%$ & $53.2 \%$ & & \\
\hline & Postgraduate level & $21.9 \%$ & $40.3 \%$ & & \\
\hline \multirow[t]{5}{*}{ Spouse's occupation } & Lecturer/Teacher & $33.6 \%$ & $34.6 \%$ & $\chi^{2}=30.29$ & ** \\
\hline & PCS/Company staff & $25.9 \%$ & $25.9 \%$ & & \\
\hline & Entrepreneur & $9.5 \%$ & $22.2 \%$ & & \\
\hline & Others & $3.4 \%$ & $14.8 \%$ & & \\
\hline & Does not work & $27.6 \%$ & $2.5 \%$ & & \\
\hline
\end{tabular}

Notes. ${ }^{*} p<0.05,{ }^{* *} p<0.01, \#=$ marginally significant, $\mathrm{ns}=$ not significant

More male than female respondents had a spouse whose highest education is high school. In addition, more male respondents have a spouse with a bachelor degree, whereas more female respondents have a spouse with doctorate education. Overall, female respondents' spouse has higher educational level $(M=3.32, S D=0.97)$ than male respondents $(M=2.81, S D=0.99), \chi^{2}(2, N=191)=9.58, \mathrm{p}<0.01$. 
Furthermore, there is a tendency that respondents have a spouse with similar type of occupations such as lecturer/teacher or public service work. However, compared to female respondents more male respondents have a spouse who does not report having a formal occupation.

In this section, we describe the results of MANOVA analyses, make interpretations, and then draw conclusions. The focus is on the gender effects on the career productivity and success. Does gender affect the productivity of academic staff? According to Table 2, the mean distribution of male academics across the six productivity indicators is higher than that of female academics. For example, the mean of men on thesis supervision is $M=1.98$ compared to that of women $M=1.87$. However, the F-test shows that only Publication was statistically significant $(p=0.00)$ for men and women, indicating that men have higher number of publications than women. This suggests that in Indonesian academia, gender matters only on publication. No significant difference was found between men and women in other productivity indicators.

Does gender affect career success of academic staff? According to Table 2, the means of academic rank, leadership positions, and income are higher for men than for women; and the F-test shows that the different means for men and women are significant. For example, the mean of men on Academic rank is $M=2.28$ compared to that of women $M=2.0$ on $p=0.03$. This indicates that men hold higher academic rank, have higher or more often have leadership positions, and earn higher income than women. Furthermore, the mean of career satisfaction for women is higher than that for men; however, the different is not statistically significant. Finally, despite the fact that the mean of work engagement for men is higher than that of women, it is not statistically significant. Men and women are equally satisfied with their career and have equal level of work engagement. Gender does have strong effect on the indicators of objective career success; but does not on subjective career outcomes. It is concluded that women are less successful than men objectively; but that men and women are subjectively indifference. 
Nur Kholis

Table 2: Means, F, and p of Career Productivity and Career Success by Gender

\begin{tabular}{|c|c|c|c|c|c|}
\hline \multicolumn{6}{|l|}{ Career productivity } \\
\hline \multirow[t]{3}{*}{ Thesis supervision } & Male & 1.98 & 1.81 & 0.17 & 0.68 \\
\hline & Female & 1.87 & 1.59 & & \\
\hline & Total & 1.94 & 1.72 & & \\
\hline \multirow[t]{3}{*}{ Committee appointment } & Male & 1.29 & 1.79 & 2.41 & 0.12 \\
\hline & Female & 0.88 & 1.56 & & \\
\hline & Total & 1.12 & 1.71 & & \\
\hline \multirow[t]{3}{*}{ Publications } & Male & 1.99 & 2.00 & 8.51 & 0.00 \\
\hline & Female & 1.20 & 1.33 & & \\
\hline & Total & 1.68 & 1.80 & & \\
\hline \multirow[t]{3}{*}{ Teaching } & Male & 16.21 & 7.73 & 0.09 & 0.76 \\
\hline & Female & 15.85 & 8.32 & & \\
\hline & Total & 16.07 & 7.95 & & \\
\hline \multirow[t]{3}{*}{ Research } & Male & 2.67 & 1.05 & 2.13 & 0.15 \\
\hline & Female & 2.44 & 1.07 & & \\
\hline & Total & 2.58 & 1.06 & & \\
\hline \multirow[t]{3}{*}{ Scholarly presentation } & Male & 0.67 & 0.47 & 0.84 & 0.36 \\
\hline & Female & 0.61 & 0.49 & & \\
\hline & Total & 0.65 & 0.48 & & \\
\hline \multicolumn{6}{|l|}{ Career success } \\
\hline \multirow[t]{3}{*}{ Academic rank } & Male & 2.28 & 0.87 & 4.72 & 0.03 \\
\hline & Female & 2.01 & 0.84 & & \\
\hline & Total & 2.17 & 0.87 & & \\
\hline \multirow[t]{3}{*}{ Leadership position } & Male & 0.94 & 0.85 & 9.78 & 0.00 \\
\hline & Female & 0.58 & 0.70 & & \\
\hline & Total & 0.79 & 0.81 & & \\
\hline \multirow[t]{3}{*}{ Monthly income } & Male & 1.87 & 0.99 & 7.49 & 0.01 \\
\hline & Female & 1.51 & 0.82 & & \\
\hline & Total & 1.72 & 0.94 & & \\
\hline \multirow[t]{2}{*}{ Career satisfaction } & Male & 3.45 & 0.78 & 0.36 & 0.55 \\
\hline & Female & 3.52 & 0.69 & & \\
\hline
\end{tabular}




\begin{tabular}{llllll}
\hline $\begin{array}{lllll}\text { Variables } \\
\text { Career productivity }\end{array}$ & Gender & $\boldsymbol{M}$ & $\boldsymbol{S D}$ & $\boldsymbol{F}$ & $\boldsymbol{P}$ \\
\hline \multirow{3}{*}{ Work engagement } & & & & & \\
& Total & 3.48 & 0.74 & & \\
& Male & 4.46 & 0.90 & 0.29 & 0.59 \\
& Female & 4.39 & 0.90 & & \\
& Total & 4.43 & 0.90 & & \\
\hline
\end{tabular}

\section{Academic Rank, Leadership Positions, and Income: An Analysis of Empirical Data}

The data shows that only on publication do women differ from men; in Islamic State Higher Education Institutions (ISHEIs) men have higher number of publication than women. This supports previous studies that men generally have higher number of publications than women..$^{50}$ There is no significant difference for other productivity indicators, indicating that the allocation of teaching loads, thesis supervision, research grants, and committee appointment are distributed to academic staff according to their expertise regardless of gender.

Publishing requires huge resources and involves an external party. The resources lectures have may determine their ability in preparing and, then, publishing their work. Women and men particularly married ones may have different resources. Literature suggests that married women are more likely to hold home responsibility than married men due to their prescribed roles, ${ }^{51}$ hereby reducing their time for publishing activity. This may also explain that publishers rate the manuscript submitted by women differently due to gender bias. Thus,

50 D'Amico, "Similarities and Differences in Women's and Men's," pp. 343-61; Hemmings, "Academics' Views On Publishing Refereed Works," pp. 307-32; Kirchmeyer, "The Different Effects of Family," pp. 323-46; D. Reed, F. Enders, L. Lindor, M. McClees, and K. Lindor, K. "Gender Differences in Academic Productivity and Leadership Appointments of Physicians Throughout Academic Careers," Acad Med, 86, 1 (2011): pp. 43-7; Symonds, "Gender Differences in Publication Output."

51 A. H. Eagly, "Social Role Theory of Sex Differences and Similarities," in J. Worell (ed.), Encyclopedia of Women And Gender: Sex Similarities and Differences and The Impact of Society on Gender (San Diego: Academic Press, 2001), pp. 1069-78.; A.H. Eagly, and S. J. Karau, "Role Congruity Theory of Prejudice Toward Female Leaders," Psychological Review, 109, 3 (2002): pp. 573-98. 
despite sending the same number of manuscripts as men, the women's may not be published.

Literature on academic career indicates that women are likely to have lower academic rank $^{52}$ and leadership positions in university ${ }^{53}$, and earn less income than men. ${ }^{4}$ We found that female academics in Indonesia also hold lower academic rank and leadership positions, and earn less than male academics. Thus, gender has a strong effect on these objective outcomes.

Late entrance to university employment, productivity level, and educational background, and gender bias operating in the performance evaluation may explain women holding lower academic rank. Historically, women are recruited into the academic profession later than men; thus, it is logical that women are in junior positions. Women may propose their rank advancement less frequently due to insufficient credit numbers, especially from publication (women publish less). Furthermore, since more women than men holding lower education levels, it is reasonable to argue that women are in lower academic rank. Finally, the evaluation on the prerequisites of academic ascending for women may also be harder than that for men. Valian coined "gender schemas" in which the expectations of evaluators for men and women influence the way they interpret the same action(s) taken by a man or a woman. One of the most important consequences [of this] for professional work is that men are consistently overrated, while women are underrated. ${ }^{55}$ These disadvantages cumulate over time to large differences between men and women in terms of promotion. ${ }^{56}$

Women holding lower leadership positions can be explained from leadership selection process, organizational bias, and individual factor.

52 Sabatier, "Profiles of Academic Activities and Careers," pp. 311-324; Sanders, "Views from Above the Glass Ceiling," pp. 301-12; F. Wright, ands J. Guth, "Women in the Higher Education Sector," The Industrial Law Journal, 38, 1 (2009): pp. 139-42.

53 AVCC, "Vice-Chancellors"; Eggins, Women in Higher Education.

54 Knapp, "Employees in Postsecondary Institutions,"; K. Monroe, S. Ozyurt, T. Wrigley, and A. Alexander, "Gender Equality in Academia: Bad News From The Trenches, and Some Possible Solutions," Perspectives on Politics, 6, 2 (2008): pp. 215-33.

55 V. Valian, "Sex, Schema and Success: What's Keeping Women Back?," Academe (September 1998).

56 M. D. Agars, "Reconsidering The Impact of Gender Stereotypes on The Advancement of Women in Organizations," Psychology of Women Quarterly, 28, 2 (2004): pp. 103-11. 
The selection of leadership position involves a degree of political activity, ${ }^{57}$ and to succeed as senior leaders in the political environment, political astuteness is an inevitable and indispensable requirement. ${ }^{58}$ However, in many societies, women are encouraged to take on the supportive and nurturing roles instead of the competitive and aggressive roles; they are socialized not to desire power; and tend to be less trained in the skills needed to play the political workplace games. ${ }^{59}$ Because of lacking in political socialization and training, many women may not only view words such as "politics" and "strategies" as dirty, but may also feel uncomfortable talking about them openly. ${ }^{60} \mathrm{~A}$ further effect is that women may have less desire for power; will not often admit to want to battle for a position; appear reluctant to play the game in the system; and are likely to lack confidence and competitiveness when it comes to the political game. ${ }^{61}$

The workplace has been male-dominated for a long time, thus they are organized around and support men's work styles and life cycles, even those that appear to be "gender-neutral" and meritocratic. ${ }^{62}$ This leads to the so called "old-boys" networks which is reluctant to let women join in, ${ }^{63}$ and often ignores and discourages women from

57 K. M. Davey, "Women's Accounts of Organizational Politics as A Gendering Process," Gender, Work \& Organization, 15, 6 (2004): pp. 650-71; Tiao, Senior Women Leaders in Higher Education.

58 D. W. Cantor, and T. Bernay, T. Women in Power (New York: Houghton Mifflin, 1992).

59 Tiao, Senior Women Leaders in Higher Education.

${ }^{60} \mathrm{~J}$. E. Albino, "Strategy: The Dirty Word That Women Must Learn," The Educational Record, 73, 2 (1992): p. 47.

${ }^{61}$ I. Oplatka, and V. Tamir, V. "I don't want to be a school head': Women deputy heads' insightful constructions of career advancement and retention," Educational Management Administration \& Leadership, 37, 2 (2009): pp. 216-38.

${ }^{62}$ J. Acker, "Hierarchies, Jobs, Bodies: A Theory of Gendered Organizations," Gender and Society, 4, 2 (1990): pp. 139-58; R. J. Ely, and D. E. Meyerson, "Theories of Gender in Organizations: A New Approach To Organizational Analysis and Change," in B. M. Staw \& R. L. Sutton (eds), Research in Organizational Behaviour (New York: JAI Press, 2000).

${ }^{63}$ M. D. Wenniger, and M. H. Conroy, Gender Equity Or Bust!: On The Road To Campus Leadership With Women In Higher Education (1 ${ }^{\text {st }}$ ed.) (San Francisco: Jossey-Bass Publishers, 2001). 
seeking leadership roles within universities. ${ }^{64}$ The prevalence of a more dominant masculine culture will generate gender bias, prejudice, and discrimination towards women. ${ }^{65}$ Women may feel less attracted to leadership position, especially the top ones, not because of their ability, but because of their organizational (male) culture preferences. ${ }^{66}$ Male domination may lead the next recruitment of future leaders to conform to the gender of the majority of existing leaders.

Finally, due to the lower qualification (education and productivity) women were more likely to self-limit because they felt they were not fulfilling the requirements for a (higher) leadership positions. In contrast, because more male than female have higher qualifications, the number of men fulfilling the requirements would higher. When more male applicants outnumber female applicants, men are more likely to be recruited for a leadership position.

Women earning less income than men may be explained by their lower academic rank and leadership position. The salary scheme operated in the state universities is solely based on the levels Public Civil Servant (PCS) rank and academic rank. There are automatic twoyearly salary increase and the incidence of salary adjustment by the government that is provided for all lecturers regardless of gender. Thus, the income of men and women in the same levels of PCS and academic ranks would have to be the same. An income gap between men and women may be explained from the differences in the levels of academic rank and of a certain position they may hold, and frequency of other income-generating activities they perform, such as publications. Thus, it is unlikely that gender background per se produces income gap.

Women and men in are equally satisfied with their career. This finding does not support early findings ${ }^{67}$ that generally men are more satisfied with their academic work than women. The result of this

${ }^{64}$ S. M. Crampton, and J. M. Mishra, "Women in Management," Public Personnel Management, 28, 1 (1999): p. 87.

${ }^{65}$ Ismail, "Barriers to Career Progression Faced By Women,” pp. 51-66.

${ }^{66}$ A. E. M. Vianen, and A. H. Fischer, "Illuminating The Glass Ceiling: The Role of Organizational Culture Preferences," Journal of Occupational and Organizational Psychology, 75 (2002): pp. 315-37.

${ }^{67}$ Okpara, "Gender Differences and Job Satisfaction," pp. 177-90; M. Sabharwal, and E. A. Corley, "Faculty Job Satisfaction Across Gender and Discipline," The Social Science Journal, 46 (2009): pp. 539-56. 
study also does not confirm early finding by Baş and Ardiç 68 that in general lecturers in state universities are less satisfied with their jobs compared to those in private universities. Lecturers in this study may perceive their work environment and outcome as having matched their need and expectation.

Previous studies indicate that women are less engaged in work than men. ${ }^{69}$ This study finds that female and male academics have equal level of work engagement. This suggests that expectation of organization towards women and men are the same. Thus, gender base expectations on work for men and women are not prevalence in ISHEIs. Men and women academics put similar efforts during their career, despite their productivity and success are different. Finally, academic work seems to provide flexibility ${ }^{70}$ so that pressure of home can be managed as such that men and women are able to fully engage in work.

\section{Conclusion}

The findings of the present study have contributed to the better understanding of career productivity and success among female and male academics in Indonesian academia. The literature on careers has not paid much attention to gender-based career dynamics in diverse cultures, and particularly in third-world countries such as Indonesia. ${ }^{71}$ The present research attempts to fill in the gap in research about career productivity and success by supplying empirical career research for Indonesian academia. In fact, this study represents one of the first to investigate comprehensively the nature of gendered-academic career in Indonesia, and more specifically within the Islamic State Higher Education Institutions (ISHEIs).

\footnotetext{
68 T. Baş, and K. Ardıç, "A Comparison of Job Satisfaction Between Public and Private University Academicians in Turkey," METU Studies in Development, 29, 1-2 (2002): pp. 27-46.

${ }^{69}$ Burke, "Work Engagement Among Managers and Professionals in Egypt," pp. 4260; D. A. Otwori, and L. Xiangping, "Empirical Study on Occupational Engagement of Kenyan Cultural Officers," Far East Journal of Psychology and Business, 1, 1 (2010): pp. 3-14.

${ }^{70}$ Beninger, Women in Academia.

${ }^{71}$ N. Kim, "Career Success Orientation of Korean Women Bank Employees," Career Development International, 9, 6 (2004): pp. 595 - 608.
} 
The results of the present study should lead to a better understanding of men and women career productivity and success during their career in academia. The fact that women publish less, have lower academic rank and leadership positions, and earn less than men deserves a comprehensive policy. The policy makers in the central department and the individual university should take necessary measures to make the organizations better facilitate the growth and the development of all members. The Islamic State Higher Education Institutions (ISHEIs) could introduce specific training for women in writing skills and provide financial and motivational support for publications. Partnership in publishing between women-men or women-women need to be encouraged too. The development in this area is crucial for the fact that publications are regarded as important or even central to an academic's life-world..$^{72}$ Academic promotion is difficult without a good publication record. ${ }^{73}$

The leadership empowerment and development for women academics may be introduced. For example, by preparing women for acquiring lower leadership positions as their training ground, so that in the future they would have wider opportunities for higher leadership positions. Finally, the ISHEIs should invest necessary effort in delineating gender bias in human resource development and maintain the harmonious diversity in the organization.]

\section{Bibliography}

\section{Books and Articles}

Acker, J. "Hierarchies, Jobs, Bodies: A Theory of Gendered Organizations." Gender and Society, 4(2) (1990): pp. 139-58.

Agars, M. D. "Reconsidering The Impact of Gender Stereotypes on The Advancement of Women in Organizations." Psychology of Women Quarterly, 28(2) (2004): pp. 103-11.

\footnotetext{
72 A. A. Ligthelm, and E. M. Koekemoer, "Academic Publishing: Lessons Learnt from the Southern African Business Review," Southern African Business Review, 13, 3 (2009): pp. 28-50.

${ }^{73}$ M. R. McGrail, C. M. Rickard, and R. Jones, "Publish Or Perish: A Systematic Review of Interventions to Increase Academic Publication Rates," Higher Education Research and Development, 25, 1 (2006): pp. 19-35.
} 
Albino, J. E. "Strategy: The Dirty Word That Women Must Learn." The Educational Record, 73(2) (1992), 47.

AVCC. "Vice-Chancellors," Retrieved November 11, 2008, from http://www.universitiesaustralia.edu.au/content.asp?page=/abo ut/current office holders/VCs.htm

Baş, T., \& Ardıç, K. "A Comparison of Job Satisfaction Between Public and Private University Academicians in Turkey," METU Studies in Development, 29(1-2) (2002): pp. 27-46.

Bayer, A. E., \& Astin, H. S. "Sex Differentials in The Academic Reward System." Science, 188(4190) (1975): pp., 796-802.

Beninger, A. "Women in Academia: A Cross-Cultural Perspective On Work/Life Balance." Unpublished Ph.D Dissertation, London School of Economics, London, UK, 2010.

Berges, S. "Women and Academic Conferences," from http://www.vitae.ac.uk/researchers/502241-352611/Women-and-academicconferences.html (2011).

BlessingWhite. "The Employee Engagement Equation in India." BlessingWhite. Retrieved August 21, 2011, from www.blessingwhite.com/content/reports/blessingwhite_2011_ee_report.pdf

Burke, R. J., \& El-Kot, G. "Work Engagement Among Managers and Professionals in Egypt: Potential Antecedents and Consequences." African Journal of Economic and Management Studies, 1(1) (2010): pp, 42-60.

Burke, R. J., \& Fiksenbaum, L. "Work Engagement Among Women Managers and Professionals in a Turkish Bank." Equal Opportunities International, 25(4) (2006)., 299-310.

Cantor, D. W., \& Bernay, T. Women in power. New York: Houghton Mifflin, 1992.

Christian, M. S., Garza, A. S., \& Slaughter, J. E. "Work Engagement: A Quantitative Review and Test of Its Relations with Task and Contextual Performance." Personnel Psychology, 64 (2011), pp. 89136.

COACHE. The Experience of Tenure-Track Faculty at Research Universities: Analysis of COACHE Survey Results by Academic Area and Gender. Cambridge, MA: Harvard Graduate School of Education, 2010. 
Cohen, L., Manion, L., \& Morrison, K. Research Methods in Education (6 ed.). Abingdon, Oxon: Routledge, 2007.

Coordinating Minister.. "Keputusan Menteri Koordinator Bidang Pengawasan Pembangunan dan Pendayagunaan Aparatur Negara No. 38/KEP/MK. WASPAN/8/1999 Tentang Jabatan Fungsional Dosen dan Angka Kreditnya (The Minister Decree on the Functional Positions of Lecturers and their Credit Numbers)," 1999.

Crampton, S. M., \& Mishra, J. M. "Women in Management. Public Personnel Management, 28(1) (1999), p. 87.

D'Amico, R., \& Canetto, S. S.. "Similarities and Differences in Women's and Men's Publication and Citation Record Among Academic Psychologists." Journal of Women and Minorities in Science and Engineering, 16(4) (2010): pp. 343-61.

Davey, K. M.. "Women's Accounts of Organizational Politics As A Gendering Process." Gender, Work \& Organization, 15(6) (2008): pp. 650-71.

De Pater, I. E. "Doing Things Right or Doing The Right Thing: A New Perspective on the Gender Gap in Career Success." Unpiblished PhD. Dissertation, Universitiet van Amsterdam, Amsterdam, 2005.

Dunkin, M. J. "Determinants of Academic Career Advancement at An Australian University." Higher Education Research \& Development, 10(2) (1991): pp. 115-31.

Eagly, A. H.. "Social Role Theory of Sex Differences and Similarities." in J. Worell (Ed.). Encyclopedia of Women and Gender: Sex Similarities and Differences and The Impact of Society on Gender. San Diego: Academic Press, 2001: pp. 1069-78.

Eagly, A. H., \& Karau, S. J.. "Role Congruity Theory of Prejudice Toward Female Leaders." Psychological Review, 109(3) (2002): pp. 573-98.

Eggins, H. "Women in Higher Education, Research and Innovation: Gains and Further Challenges." Paper presented at the 2009 World Conference on Higher Education (Paris, 5-8 July 2009), Unesco Paris. 
Ely, R. J., \& Meyerson, D. E. "Theories of Gender in Organizations: A New Approach to Organizational Analysis and Change." in B. M. Staw \& R. L. Sutton (Eds.). Research in Organizational Behaviour. New York: JAI Press, 2000.

Engen, M. L. v., Bleijenbergh, I. L., \& Vinkenburg, C. J. Structural and Cultural Barriers For The Advancement of Women at Delft University of Technology. Delft, NL.: Delft University of Technology, 2010.

Garfinkel, P. E., Bagby, R. M., Schuller, D. R., Dickens, S. E., Schulte, F. S., \& Fitzgerald, L. "Gender Differences in the Practice Characteristics and Career Satisfaction of Psychiatrists in Ontario." Acad Psycbiatry, 28(4) (2004): pp. 310-20.

Gerson, L., Twomey, K., Hecht, G., Lee, L., McQuaid, K., Pizarro, T., Early, D. "Does Gender Affect Career Satisfaction and Advancement in Gastroenterology? Results of an AGA Institute-Sponsored Survey." Gastroenterology, 132(4) (2007): pp. 1598-1606.

Greenhaus, J. H., Parasuraman, S., \& Wormley, W. M. "Effects of Race on Organizational Experiences, Job Performance Evaluations, and Career Outcomes." Academy of Management Journal, 33 (1990), 64-86.

Hancock, K. J., \& Baum, M. "Women and Academic Publishing: Preliminary Results From A Survey of The ISA Membership." Paper presented at the The International Studies Association Annual Convention, New Orleans, LA, 2010.

Hemmings, B., Rushbrook, P., \& Smith, E. "Academics' Views on Publishing Refereed Works: A Content Analysis." Higher Education, 54(2) (2007): pp. 307-32.

Indonesian Govt. Peraturan Pemerintah Republik Indonesia Nomor 60 Tabun 1999 Tentang Perguruan Tinggi (Government Regulation on Higher Education), (1999).

Ismail, M. "Barriers to Career Progression Faced By Women: Evidence From A Malaysian Multinational Oil Company." Gender in Management: An International Journal, 23(1) (2008): pp. 51-66.

Kern, M. L., Friedman, H. S., Martin, L. R., Reynolds, C. A., \& Luong, G. "Conscientiousness, Career Success, and Longevity: A 
Lifespan Analysis." Annals of Behavioral Medicine, 37 (2009): pp. 154-63.

Kim, N. "Career Success Orientation of Korean Women Bank Employees." Career Development International, 9(6) (2004): pp. 595 -608 .

Kirchmeyer, C. "Determinants of Managerial Career Success: Evidence and Explanation of Male/Female Differences." Journal of Management, 24(6) (1998): pp. 673-92.

Kirchmeyer, C. The Different Effects of Family on Objective Career Success Across Gender: A Test of Alternative Explanations." Journal of Vocational Behavior, 68(2) (2006): pp. 323-46.

Knapp, L. G., Kelly-Reid, J. E., \& Ginder, S. A.. "Employees in Postsecondary Institutions, Fall 2009, and Salaries of Full-Time Instructional Staff, 2009-10 (NCES 2011-150). U.S. Department of Education." Washington, DC: National Center for Education Statistics. Retrieved August 17, 2011, from http://nces.ed.gov/pubsearch

Kong, Y. "A Study on The Job Engagement of Company Employees." International Journal of Psychological Studies, 1(2) (2009): pp. 65-8.

Ligthelm, A. A., \& Koekemoer, E. M. Academic Publishing: Lessons Learnt from the Southern African Business Review." Southern African Business Review, 13(3) (2009): pp. 28-50.

Loughlin, S. "Barriers To Women's Career Progression: A Review of The Literature." http://www.ssc.govt.nz. Working Paper No. 6. The State Services Commission New Zealand. Crown, NZ, (2000).

McGrail, M. R., Rickard, C. M., \& Jones, R.. "Publish or Perish: A Systematic Review of Interventions to Increase Academic Publication Rates." Higher Education Research and Development, 25(1) (2006): pp. 19-35.

Monroe, K., Ozyurt, S., Wrigley, T., \& Alexander, A. "Gender Equality in Academia: Bad News from the Trenches, and Some Possible Solutions." Perspectives on Politics, 6(2) (2008): pp. 215-33.

MoRA. Education Statistic 2007/2008. Jakarta: Directorate of Islamic Higher Education, 2008. 
Ng, T. W. H., Eby, L. T., Sorensen, K. L., \& Feldman, D. C. "Predictors of Objective and Subjective Sareer Success: A MetaAnalysis." Personnel Psychology, 58 (2005): pp. 367-408.

Okpara, J. O., Squillace, M., \& Erondu, E. A. (2005). Gender Differences and Job Satisfaction: A Study of University Teachers in the United States." Women In Management Review, 20(2) (2005): pp. 177-90.

Oplatka, I., \& Tamir, V.. "'I Don't Want To Be A School Head': Women Deputy Heads' Insightful Constructions of Career Advancement and Retention." Educational Management Administration \& Leadership, 37(2) (2009): pp. 216-238.

Oshagbemi, T.. "Is Length of Service Related To The Level of Job Satisfaction?" International Journal of Social Economics, 27(3) (2000): pp. 213-26.

Otwori, D. A., \& Xiangping, L. "Empirical Study on Occupational Engagement of Kenyan Cultural Officers." Far East Journal of Psychology and Business, 1(1) (2010): pp. 3-14.

Reed, D., Enders, F., Lindor, R., McClees, M., \& Lindor, K.. Gender Differences in Academic Productivity and Leadership Appointments of Physicians Throughout Academic Careers." Acad Med, 86(1) (2011): pp. 43-47.

Sabatier, M., Carrere, M., \& Mangematin, V.. Profiles of Academic Activities and Careers: Does Gender Matter? An Analysis Based on French Life Scientist CVs." Journal of Technology Transfer, 31(2006): pp. 311-24.

Sabharwal, M., \& Corley, E. A.. "Faculty Job Satisfaction Across Gender and Discipline." The Social Science Journal, 46 (2009):pp. 539-56.

Sanders, K., Willemsen, T. M., \& Millar, C. C. J. M. "Views From Above The Glass Ceiling: Does The Academic Environment Influence Women Professors' Careers and Experiences?" Sex Roles, 60(5-6) (2009): pp. 301-12.

Schaufeli, W. B., Bakker, A. B., \& Salanova, M. The Measurement of Work Engagement With A Short Questionnaire." Educational and Psychological Measurement, 66(4) (2006): pp. 701-716. 
Seibert, S. E., Kraimer, M. L., \& Liden, R. C.. "A Social Capital Theory of Career Success." The Academy of Management Journal, 44(2) (2001): pp. 219-37.

Sonnentag, S.. "Recovery, Work Engagement, and Proactive Behavior: A New Look at the Interface Between Nonwork and Work." Journal of Applied Psychology, 88(3) (2003): pp. 518-28.

SPSS.. PASW® Statistics 18 Core System User's Guide. Chicago, IL.: SPSS Inc., 2009.

Symonds, M. R. E., Gemmell, N. J., Braisher, T. L., Gorringe, K. L., \& Elgar, M. A. "Gender Differences in Publication Output: Towards An Unbiased Metric of Research Performance." PLoS ONE, 1(1) (2006): p. e127.

Takahashi, A. M., \& Takahashi, S. "Gender Salary Differences in Economics Departments in Japan." Paper presented at the Kansai Labour Seminar, Osaka University, 2009.

Tiao, N.-C. "Senior Women Leaders in Higher Education: Overcoming Barriers To Success." Unpublished PhD. Dissertation, Eastern Michigan University, Ypsilanti, Michigan, 2006.

Valian, V. "Sex, Schema and Success: What's Keeping Women Back?," Academe (September 1998).

Vianen, A. E. M., \& Fischer, A. H. "Illuminating the Glass Ceiling: The Role of Organizational Culture Preferences." Journal of Occupational and Organizational Psychology, 75 (2002): pp. 315-37.

Wenniger, M. D., \& Conroy, M. H. Gender Equity or Bust:: On the Road to Campus Leadership with Women in Higher Education (1st ed.). San Francisco: Jossey-Bass Publishers, 2001.

Winslow, S. "Gender Inequality and Time Allocations Among Academic Faculty." Gender \& Society, 24(6) (2010): pp. 769-93.

Wright, F., \& Guth, J. "Women in the Higher Education Sector." The Industrial Law Journal, 38(1) (2009): pp. 139-42. 